\title{
Psychodrama Practices in Adolescents
}

\section{Ergenlerde Psikodrama Uygulamalart}

\author{
Çağlar ŞİMŞEK ${ }^{1}$, Leyla KÜÇÜK² ${ }^{2}$, Ejder Akgün YILDIRIM ${ }^{3} \odot$

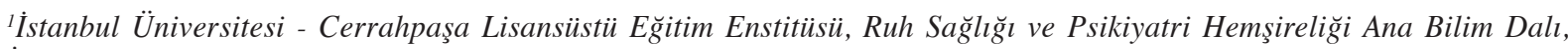 \\ Istanbul, Türkiye \\ ${ }^{2}$ İstanbul Üniversitesi - Cerrahpaşa Florence Nightingale Hemşirelik Fakültesi, Ruh Sağlı̆̆ı ve Psikiyatri Hemşireliği Ana \\ Bilim Dall, İstanbul, Türkiye \\ ${ }^{3}$ Sağlık Bilimleri Üniversitesi Bakırköy Prof. Dr. Mazhar Osman Ruh Sağlı̆̆ı ve Sinir Hastalıkları Ĕ̈itim ve Araştırma \\ Hastanesi, İstanbul, Türkiye
}

\begin{abstract}
Adolescence when physical changes are rapidly experienced and when the sense of identity begins to form is a process of transition from childhood to adulthood.P sychodrama is a method of group psychotherapy that aims to treat an individual within a group and in which action techniques are used. With this aspect, it is known that psychodrama, a technique based on action, is more effective than verbal and hermeneutical techniques. When understood accurately and used well, psychodrama becomes an effective method that can provide insight, catharsis, integration and change for the behaviour of the individual.
\end{abstract}

Keywords: Psychodrama, psychotherapy, adolescents
ÖZ

Ergenlik dönemi, fiziksel değişimlerin hızlı bir şekilde

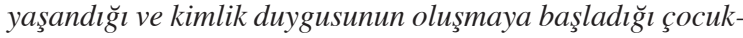
luktan yetişkinliğe geçişin olduğu süreçtir. Psikodrama, bireyin grup içinde iyileştirilmesini hedefleyen, aksiyon tekniklerinin kullanıldı̆̆ bir grup psikoterapi yöntemidir. Bu yönü ile ergen gruplarında eyleme dayalı bir teknik olan psikodramanın, sözel ve yoruma dayal tekniklerden daha etkin bulunduğu bilinmektedir. Psikodrama, doğru anlaşıldı ̆̆ $\mathrm{v}$ ve iyi kullanıldı ğında bireyin, davranışına içgörü, duygusal boşalım, bütünleşme ve değişim să̆layabilen, etkili bir yöntemdir.

Anahtar kelimeler: Psikodrama, psikoterapi, ergenler

\section{INTRODUCTION}

Human life may be mainly divided into six stages as childhood, adolescence, early adulthood, mature adulthood, late adulthood and old ages. A certain and successive progress is observed in human development. The previous development stage forms a basis for the next stage (1). World Health Organization (WHO) defines the ages between 0 and 2 as infancy, ages between 2 and 9 as childhood and ages between 10 and 19 as adolescence ${ }^{(2)}$.
Adolescence is a process of transition from childhood to adulthood where physical changes are rapidly experienced and the sense of identity begins to form (2). Adolescence in which there is a transition from childhood to adulthood, and some individuals experience stressful and a great number of conflicts may be a challenging process when rapid changes are experienced in several developmental areas that carry a great importance in the process of identity achievement ${ }^{(3)}$. In this period, the most notable changes are seen in the areas of physical and psychological development. Increase in height, weight gain, hair growth 
on the body, and hormonal changes are the main physical changes. However, the major developmental area in which the adolescent gets confused is its psychological dimension. During this period, adolescents seek autonomy and have conflicts with their parents. They also feel affectation and emotional closeness to each other. However, they experience some problems such as running away from school, smoking, trying drugs, involving in illegal events, manifesting inconsistent and changing moods, anger and aggression. Adolescents who can effectively cope with these problems achieve an identity acquisition, which is the most important developmental task of adolescence ${ }^{(4-6)}$. However, adolescents who can not cope with these problems in a healthy and effective way may face negative consequences ranging from alcohol and drug use to tendency to commit crime $^{(7)}$.

In order to overcome the adolescence without any problem, it is necessary to care for adolescents, be careful against possible problems, support them and be flexible within the process ${ }^{\left({ }^{8}\right)}$. Individuals who have a positive self-image, who are social, easy-going and dynamic, who have plans for the future, and gained their physical, psychological and material autonomy at the same time, and succeeded in reaching satisfaction through their interests beyond their ordinary concerns are defined as healthy adolescents subjected to the principle of physical, psychological and social reality ${ }^{(9)}$.

Psychodrama is a method of group psychotherapy that offers the individual the chance to get over the difficulties within a group using action techniques. Life realities are simulated in a group room and acted out by the group members as a dramatic play. Solutions are sought for the problems by using group creativity and spontaneity ${ }^{(10)}$. Psychodrama is practiced by psychiatrists, physicians, social care specialists, psychologists and psychiatry nurses with special training. In this context, this review aimed to shed light on the use of psychodrama in adolescents.

\section{DEFINITION AND TECHNIQUES OF PSYCHODRAMA}

Psychodrama is a method of psychotherapy in which the individuals are directed to display their behaviours in dramatic ways such as expressing themselves and playing a role. The original theory of psychodrama was proposed by Jacob Levy Moreno. According to Moreno, psychodrama is a science investigating the presence of human being and their realities in different life situations with dramatic methods ${ }^{(11)}$.

Role is an interpersonal experience and an inseparable part of social life and even social life consists of roles. As soon as a baby is born, it leaves behind its embryonal life and plunges into an external environment, in other words, into a social environment where he or she will play some roles. As development and growth proceed, these roles develop and expand as well. It is known that most of the psychological and physical disorders result from unhealthy life experiences in the role stages of a child. If the life of an individual is patterned with such roles, it would be more accurate for this individual to analyse his or her physical and psychological disorders within a group in which he/she will experience these roles ${ }^{(11,12)}$.

Psychodrama sessions consist of three phases as warm-up, acting-out and sharing. A psychodrama session generally starts with the warm-up of the leader. During this warm-up process, a psychodramatist should firstly be aware of the important things that he/she is going through, look over the characteristic features, and previous review of the group he/ she will direct and be prepared for the session in such a way that it does not prevent his or her spontaneity or make recognition of the the needs of the group difficult at the same time ${ }^{(13)}$. The action phase starts when the protagonist leaves the group during the warm-up process, comes on the stage, choose the auxiliary ego and creates the scene where the event takes place by using existing objects for a part of the scene and by defining another part. Thus, the action of dramatizing the subject established by the group through gathering within a common life begins. Readiness is to defeat one's resistance, to put himself or herself into the event and to be able to express and re-enact the emotional life that he/she wants to tell within the group and in the action freely without controlling or restraining himself or herself. Therefore, 
as an important issue, with acting-out verbal expression of the protagonist is transformed into different forms and the past, future and dreams are simulated as if they are existing at present ${ }^{(14)}$. While role-playing method itself can arouse intense feelings and stimulate loss of control, it can increase control if basic psychodrama techniques are conveniently used. Sharing phase in psychodrama is as important as action phase. In this phase, auxiliary egos provide feedback. Some of the group members give identification feedback and the associations of group members about their own lives are discussed in the group. The most important basic rules of this phase are as follows: group member should never comment, criticize or judge the protagonist. The sharing phase should be meticulously followed and members who make a mistake should be immediately warned and prevented by the director ${ }^{(13,15)}$.

Basic techniques of psychodrama are role reversal, doubling and mirroring. In role reversal technique, the protagonist reverses with auxiliary ego and becomes "him/her" and speaks from "his/her" perspective. The protagonist reverses all the roles on the stage and can see them from the opposite site. In doubling technique, the feelings and thoughts of which the protagonist is aware or unaware are expressed aloud in order to raise awareness. The person who does doubling stands behind the protagonist, places a hand on protagonist's shoulder and says the feelings and thoughts of the protagonist. In mirroring technique, the protagonist observes a part or parts of his or her life that he/she acted out on the stage. With this technique, the protagonist has a chance to observe his or her behaviours from outside like someone who is looking at the mirror and evaluate and change them if necessary ${ }^{(16)}$. The mirroring technique allows everyone to look at their own existential states from a distance, like watching them from a balcony ${ }^{(17)}$. Psychodrama techniques present an approach that can be integrated into an ongoing therapy, or a vocational education conducted by specialists or these techniques can be used as a part of self-help or personal development groups. Unfinished works or coping with any loss is an important theme in most people's life. Even knowing that there is a method to try to cope with these feelings is relaxing and guiding on its own ${ }^{(18)}$. The action phase in which psychodrama methods are used is followed by the sharing and providing feedbacks at the end of the group session ${ }^{(19)}$. Studies have revealed that psychodrama not only allows the individual to reframe his or her own experiences but also allows him or her to put together the parts of previously fragmented self ${ }^{(20)}$.

\section{USE OF PSYCHODRAMA IN ADOLESCENTS}

The concept of psychodrama started with observing a group of children and their games. When Moreno was a medical student, he spent most of his time by observing children in the parks of Vienna. His first "elements of psychodrama" were children. This observation of Moreno formed later a basis for the development of psychodrama which was a psychotherapeutic model ${ }^{(21,22)}$.

Games and children are important for the emergence and development of psychodrama therapy because childhood is the most beautiful and important stage of life in the formation process of self-concept and in that stage, the child receives and learns the most and confers the role of a parent to the other. Children receive and demand care; even if they do not, they are loved, protected and kept safe. On the other hand, there are conditions in which the most constant positioning of this role is disrupted. These conditions may profoundly affect and disrupt child's several sociometric, psychodramatic and psychic characteristics that he or she has developed so far. These conditions disrupt their" good" world and the relationship with their" good" world. Psychodrama is important in restoring this disrupted relationship because it is based on the creativity and spontaneity of acting-out ${ }^{(23)}$. With this aspect, it is a very convenient method to be used in children and adolescents. While practicing with children and adolescents, the selection, and integration of the approaches and recommended techniques are important for the success of the group therapy. It is important to develop an integrated therapy model in order to meet the therapeutic needs of children and adolescents ${ }^{(21)}$.

Psychodrama is an effective therapeutic method increasingly used in psychotic children and adolescents, for the management of behavioural problems of children and adolescents, stress disorder after 
trauma, adaptation problems, eating disorders, drug addiction, resolution of grief and identity confusion in adolescents (21) Because psychodrama provides children and adolescents with the opportunity to enact, direct and realize their traumas in addition to providing communication with other group members. These opportunities become effective in the resolution of psychiatric symptoms in children and adolescents ${ }^{(24)}$.

Psychodrama is also concerned with healthy people and personality development as well as unhealthy people by its nature and structure. Children can improve themselves within a group in terms of personality, and emotional development, accurate selfexpression, coping with anger, assertiveness and many other issues. With this aspect, it is obvious that every healthy child will benefit from group practices ${ }^{(25)}$.

\section{STUDIES ON PSYCHODRAMA IN ADOLESCENTS}

Psychodrama is based on creativity and spontaneity as a model using action as a base. With this aspect, it is a very convenient method to be used in children and adolescents ${ }^{(26)}$. Psychodrama and other creative arts function as a bridge to subconscious and change negative cycles and allow the member's positive characteristics of which he/she is unaware to be analysed and integrated (27). It was proved that therapy methods used in adolescents combined with psychodrama were effective in eating disorders, drug use, risky sexual behaviours, academic failure and violence prevention programs prepared for adolescents ${ }^{(28)}$.

Although studies on the use of psychodrama in children and adolescents have increased in literature, psychodrama, like other psychotherapy approaches, is criticised due to the limitations of research findings on its effectivity. As the number of studies on how psychodrama techniques are processed, which criteria are required to become a psychodrama therapist and whether it is useful as a psychotherapy method increases, the place of psychodrama in the field of psychotherapy will be more prominent. The results of the controlled studies on psychodrama have revealed that psychodrama is a theory and technique contributing to psychotherapy when applied alone or with behavioural, psychoanalytic and existential psychotherapies by therapists who correctly perform their functions and received a relevant current training ${ }^{(29,30)}$. Functions such as providing catharsis and developing insight, facing and testing the facts, and having a broader repertoire of roles and behaviour changes in psychodrama can be used as therapeutic tools in many psychological problems such as behavioural problems in psychotic and pre-psychotic children and adolescents, adaptation problems in adolescents who are going through identity confusion, stress disorders after trauma, drug addiction, eating disorders and resolution of grief ${ }^{(20)}$.

\section{CONCLUSION}

As the number of evidence-based studies on the utility of psychodrama in adolescents as a psychotherapy method increases, the place of psychodrama in this field will be more prominent. The results of controlled studies on psychodrama by therapists who have received a current training on this subject reveal that it is an effective method in the field of child and adolescent psychotherapy with its wide flexibility and expansions in the direction of development, growth and emotional learning. Nowadays, mental health and psychiatry nurses are interested in psychodrama, receive psychodrama training and use this training both in the field and in the academic life, which will contribute to the development of mental health services and community mental health.

Conflict of Interest: There is no conflict of interest between authors.

Funding: It was not taken.

Çıkar Çatışması: Yazarlar arası çıkar çatışması yoktur.

Finansal Destek: Alınmamıştır. 
Tablo 1.

\begin{tabular}{lllll}
\hline No & Author & Subject of the Study & Pattern & Result \\
\hline 1. & $\begin{array}{l}\text { Gunduz } \\
(1996),\end{array}$ & $\begin{array}{l}\text { Analysis of depression, trait and } \\
\text { state anxiety levels, impulse cont- } \\
\text { rol and coping capacity in ado- } \\
\text { lescent female students between }\end{array}$ & $\begin{array}{l}\text { Pre-test post-test } \\
\text { lentrol group design }\end{array}$ & $\begin{array}{l}\text { It was reported that the levels of depression and trait and state anxi- } \\
\text { of the self were higher than those of the control group }{ }^{(30)}\end{array}$
\end{tabular}

2. Bulut Analysis of the effect of psychod(1997), rama on social adaptation in female adolescents in the orphanage

3. Dokmen The effect of psychodrama on (1988), the level of empathy in students control group design

Pre-test post-test

It was reported that the results of social adaptation skills were more $\begin{array}{ll}\text { Pre-test post-test } & \text { It was reported that the results of social adaptation sk } \\ \text { control group design } & \text { positive in the members of psychodrama group }{ }^{(31)} \text {. }\end{array}$

4. Gokler Analysis of the effect of psychod- Qualitative study (1998), rama on adolescents perimental group obtained from Empathic Tendency Scale after psychodrama ${ }^{(32)}$.

It was reported that they tested the therapists and the technique generally; after adapting to the method, they realized their responsibilities for themselves within the group and for the process and embraced the group, as a result, a process of initiative, maturation and self-actualization was experienced ${ }^{(33)}$.

5. Ozdag Analysis of self-respect, assertive- Pre-test post-test It was reported that although higher scores of self-respect, asserti(1999), ness and empathic tendency effects control group design dents at the college of nursing $\begin{array}{ll}\text { 6. Derebasi } & \text { The effect of psychodrama du- } \\ \text { (2001), } & \text { ring the self-recognition process }\end{array}$ of the university students

veness and empathic tendency skills were obtained in psychodrama practices compared to the control group, a significant difference was only found in empathic tendency skills ${ }^{(34)}$.

It reported that belonging to a group, being able to express themselves within a group, realizing that they were not the only ones with problems, being able to face with their own realities during the group process and receiving feedbacks from the group members had beneficial effects on participant adolescents ${ }^{(35)}$.

7. Dilsiz Psychodrama practice with a Qualitative study (2001), group of high school students who experienced and did not experience Marmara earthquake by using sociometric and psychodrama techniques

8. Yerlikaya Psychodrama practice with a Qualitative study (2001), group of students who prepare for university exam

9. Yurtseven Theeffectofpsychodramaonempat- Qualitative study (2004), hic tendency and self-representation in university students

It was reported in the study conducted with a group of high school students who experienced and did not experience Marmara earthquake by using sociometric and psychodrama techniques that problems related to the adolescence became prominent, that family, peer, school management and teacher relationships were analysed and that future designs in new role trials became prominent. However, it was found that the young avoided facing individual problems and especially feelings of grief and loss ${ }^{(36)}$.

It was reported that two group members got rid of the effects of painful experiences during the process analyses according to the theory of role and that their awareness about how psychic roles with negative features prevented them from performing other social roles increased ${ }^{(37)}$.

An improvement was observed in empathic tendency and selfrepresentations of the students ${ }^{(38)}$.

10. Sen (2007),

The effect of psychodrama on Pre-test post-test the level of anxiety in students control group design who prepare for university exam
It was reported that no significant difference between the groups was found in terms of the anxiety scale for exam and that psychodrama group coincidentally had higher scores in sub-scales such as concerns about how others see you, concerns about how you see yourself, concerns about the future, physical reactions, mental reactions and general anxiety for exam ${ }^{(39)}$.

It was found that group members who split up at the beginning of the group process increased their work efficiency but still avoided to forget their troubles with fun activities ${ }^{(40)}$.

It was reported that cognitive behavioural techniques were more effective than psychodrama sessions on total score of aggression and the scores of physical aggression and anger. However, it was stated in monitoring studies that no significant difference was found between the results of post-test and monitoring measurements of aggression total score and the scores of physical aggression, verbal aggression, hostility and indirect aggression ${ }^{(41)}$. 
Tablo 1. (devam).

13. Erdogan The effect of psychodrama prac- Pre-test post-test (2010), tice on coping skills in university control group design students who had a traumatic life

14. Karatas (2011),

The effect of psychodrama on Pre-test post-test conflict resolution in high school control group design students

15. Albayrak The effect of psycho-education Pre-test post-test (2013), group practice and psychodrama- Quasi-experimental based group counselling practice design on the level of well-being of the university students

16. Akinsola The effect of psychodrama prac- Pre-test post-test and Udoka tice on the level of anxiety in Quasi-experimental (2013), children design

17. Dehnavi Psychodrama practice in decre- Pre-test post-test et al. (2014), asing social anxiety disorder in control group design male adolescents

18. Simsek The effect of psychodrama on Pre-test post-test et al. (2017) the level of social anxiety and Quasi-experimental empathy in adolescents design

19. Simsek Analysing the effect of psychod- Pre-test post-test et al. (2018), rama on the level of adaptation Quasi-experimental and assertiveness in neglected design and abused adolescents

20. Dogan The effect of psychodrama on Pre-test post-test (2018), empathy, counselling skills and control group design self-awareness in students

21. Pratama The effect of group counselling Pre-test post-test et al.(2019), using psychodrama and soci- Quasi-experimental odrama techniques to develop design emotional intelligence
It was reported in the study of psychodrama with university students who had a traumatic life that significant differences were found in favour of post-test in the control group as a result of Overstimulation sub-test in the evaluation of the Impact of Event Scale and in the experimental and control groups as a result of Mental Disengagement sub-test in the evaluation of Coping Attitudes Scale ${ }^{(42)}$.

It was reported that the scores of aggression in sub-dimension of conflict resolution decreased and the scores of problem solving skills increased in students in the experimental group when compared to those in the control group ${ }^{(43)}$.

It was stated that psychodrama was effective in increasing the psychological well-being levels of university students ${ }^{(44)}$.

It was found that psychodrama practice was effective in decreasing the levels of anxiety in children ${ }^{(45)}$

A significant decrease was found in the symptoms of social anxiety among the adolescents in the experimental group when compared to those in the control group ${ }^{(46)}$.

A significant decrease in social anxiety levels of the members and when the cases were individually evaluated, an increase in the scores of empathy were observed at the end of group therapy with adolescents by using psychodrama technique. It was reported that the change in empathic approach could be measured better by increasing the number of group members and that better results could be obtained with a recording method compatible with qualitative analysis ${ }^{(47)}$.

It was observed that adaptation of the children to the group and the living area increased at the end of psychodrama group therapy. In addition, it was reported that conciliatory communication methods, adaptation and positive experiences were achieved among children; the levels of assertiveness increased and changes in social atoms and social support networks improved and adaptation increased ${ }^{(48)}$

It was found that psychodrama increased empathy, counselling skills and self-awareness in students ${ }^{(49)}$

It was found that psychodrama and sociodrama techniques were effective in the development of emotional intelligence ${ }^{(50)}$.

\section{REFERENCES}

1. Kulaksızoğlu A. Ergen Psikolojisi, 3. Basım, İstanbul, Remzi Kitabevi. 2000. s.17-8.

2. World Health Organization. Ergenlik.http:www.who.int/ topics/adolescent_health/en/Erişim tarihi:10.10.2019.

3. Andiç S. Ergenlik döneminde zihni meşgul eden konularla ilişkili değişkenler: Bağlanma tarzları, öz-şefkat ve psikolojik belirtiler. Ankara Üniversitesi, Sosyal Bilimler Enstitüsü, Psikoloji anabilim Dalı, Yüksek Lisans Tezi. 2013.
4. Kuruoğlu AÇ, Aysev AS, and Taner YI. (Eds.), Ergenlik dönemi. Çocuk ve ergen ruh sağlığı ve hastalıkları. İstanbul: Golden Print. 2007, 1989-2206.

5. Berk EL. Çocuk gelişimi. (Çev. Ali Dönmez). Ankara: İmge Kitabevi. 2013. s.

6. Cüceloğlu, D. (http://www.dogancuceloglu.net/yazilar/520ergenlik-ve-ofke-sorusu.erişim tarihi:01 Nisan 2016.

7. Basut E. Stres, başa çıkma ve ergenlik. Çocuk ve Gençlik Ruh Sağlığı Dergisi. 2006;13(1):31-6. 
8. Gül SK, Güneş İD. Ergenlik dönemi sorunları ve şiddet Ankara Üniversitesi Sosyal Bilimler Fakültesi Dergisi. 2009;11(1):79-101.

9. Jeammet P. Ergenlik, Anne Babalar ve Uzmanlar İçin Nirengi Noktaları. (Çev.: MI. Ertüzün) İstanbul, Bağlam Yayıncılık 2012. s.15-9.

10. Schützenberger-Ancelin A. Psikodrama Yöntemlerinin Bir Özet Sunumu (Çev.:A Özbek), Grup Terapileri Derneği, Yayin No:4.1995. s.89-91.

11. Fortune DG, Richards HL, Griffiths CE, Main, CJ. Psychological stress, distress and disability in patients with psoriasis: consensus and variation in the contribution of illness perceptions, coping and alexithymia. British Journal of Clinical Psychology. 2002;41(2):157-74. [CrossRef]

12. Picardi, A, Mazzotti E, Gaetano P, Cattaruzza, MS, Baliva, G, Melchi, CF, Pasquini P. Stress, social support, emotional regulation, and exacerbation of diffuse plaque psoriasis. Psychosomatics. 2005;46(6):556-64. [CrossRef]

13. Altınay D. Psikodrama 400 ssınma oyunu ve yardımcı teknik, İstanbul: Sistem Kitabevi. 2009. s.45-51.

14. Leutz G, Özbek A. Psikodrama grup terapisinde sahnesel etkileşim, J.L. Moreno'ya göre psikodrama, 2. Basım, Dr. Abdülkadir Özbek Psikodrama Enstitüsü Yayınları, No:1.2003. s.31-51.

15. Kellermann PF. Travmayla örselenmiş kişilerle psikodramanın iyileştirici yönleri. Travmadan Sağ kalanlarla Psikodrama: Acıyı Eyleme Dökmek içinde (Ed., P. F. Kellermann, M. K. Hudgins. (S. Ünal, Çev. Ed.; B. Gökengin, Çev.). Ankara: Nobel. 2013. s.23-38.

16. Dökmen Ü. Sosyometri ve psikodrama, 3. Bask1, İstanbul: Sistem Yayınc1lık. 2011. s.176-80.

17. Bouza MF, Barrio JAE. Kisa psikodrama ve yas. Travmadan Sağ Kalanlar, Psikodrama Acıyı Eyleme Dökmek içinde (1. bask1) (ss. 51-62). (Ed., P.F. Kellermann, M.K., Hudgins) (Çev. Ed: S Ünal). Ankara: Nobel yayınları. 2013. s.51-62.

18. Blatner A. Psikodramanın Temelleri Tarihçe, Kuram, Uygulama, (Çev: G Şen) 1. Basım, İstanbul, Sistem Yayınc1lı. 2002. s.279.

19. Dökmen Ü. Sosyometri ve psikodrama. İstanbul: Remzi. 2013. s.157-70.

20. Gümüş F. Toplumsal travmaya maruz kalan bireylerde psikodrama ve grup terapisinin travma sonrası stres bozukluğu, anksiyete ve depresif belirti sıklı̆̆ına etkisi. Abdülkadir Özbek Psikodrama Enstitüsü. 2018.

21. Gökler B, Danışman I. Çocuk ve ergenlerle grup psikoterapisi ve psikodrama. Dr. Abdülkadir Özbek Psikodrama Enstitüsü Dergisi. 2011;(3):7-28.

22. Kayır A. Psikanaliz yazıları: Psikodramanın Türkiye'ye Gelişi ve Gelişimi. İstanbul: Bağlam Yayınları. 2012. s.100.

23. Yıldırım EA. Alemdar sineması vakıası ve sıradan insanın saldırganlığı üzerine sosyal psikolojik ve nöroevrimsel tezler. İçinde Barış kitabı: Bireyden topluma savaşın ve barışın ruh hali. Ankara.Türkiye Psikiyatri Derneği Yayınlar1. 2015. s.13-41.

24. Tavkar P, Hansen DJ. Interventions for families victimized by child sexual abuse: Clinical issues and approaches for child advocacy center-basedservices. Aggression and Violent Behavior. 2011;16(3):188-99. [CrossRef]

25. Altınay D. Çocuk psikodraması. İstanbul: Sistem. 2011. s.46-63.

26. Bahar G. Bir grup psikoterapisi yöntemi olarak psikodrama. Turkiye Klinikleri J Child Psychiatry-Special Topics. 2017;3(2):77-83.

27. Tasconi F. Sandrama: Psychodramatic sand tray with a trauma survivor. The ArtsinPsychotherapy.1998;25(1):21-9. [CrossRef]

28. Gatta M, Lara DZ, Lara DC, Andrea S, Paolo TC Giovanni C. Analytical psychodrama with adolescents suffering from psycho-behaviora ldisorder: Short-termeffects on psychiatric symptoms. The Arts in Psychotherapy. 2010;37(3):240-7. [CrossRef]

29. Kellermann PF. Focus on Psychodrama: The Therapeutic Aspects of Psychodrama. London: Jecssica Kingley Publishers Ltd. 1992.

30. Wilkins P. Psychodrama. London: Sage Publications Ltd. 1999. p.124-33.

31. Gündüz G. Yetiştirme yurdunda yaşayan 12-18 yaş arası kız çocuklarının psikodrama öncesi ve sonrası kişilik özelliklerinin ve sosyal uyumlarının karşılaştırılması, Uludağ Üniversitesi, Yüksek Lisans Tezi. 1996.

32. Bulut I. Yetiştirme yurdunda kalan kızlarla psikodrama, Psikodramatistlik Tezi. Abdülkadir Özbek Psikodrama Enstitüsü.1997.

33. Gökler B. Psikodrama yoluyla tedavi gören bir ergen grubunun süreç analizinde simgelerin kullanımı, Psikodramatistlik Tezi. Abdülkadir Özbek Psikodrama Enstitüsü. 1998.

34. Özdağ Ş. Psikodrama gruplarının hemşirelik yüksekokulu ögrencilerinin benlik saygısı, atılgan davranıs, empatik eğilim ve empatik beceri düzeylerine etkisi. Doktora Tezi, Hacettepe Üniversitesi. 1999.

35. Derebaşı I. Üniversite öğrencilerinin kendilerini tanıma süreçlerinde psikodramanın etkisi, Psikodrama Tezi. Abdülkadir Özbek Psikodrama Enstitüsü. 2001.

36. Dilsiz A. Bir ergen grubunun psikodrama uygulaması ve gruptan okula yönelen sosyometrik inceleme, Psikodrama Tezi. Abdülkadir Özbek Psikodrama Enstitüsü. 2001. 
37. Yerlikaya Z. Üniversiteye hazırlanan gençlerle yapılan psikodrama grubu ve iki üyenin rol teorisine göre süreç analizi, Psikodramatistlik Tezi, Abdülkadir Özbek Psikodrama Enstitüsü. 2001

38. Yurtseven F. Üniversite öğrencilerinin sosyal beceri gelişiminde psikoramanın yeri, Psikodrama Tezi. Abdülkadir Özbek Psikodrama Enstitüsü. 2014.

39. Şen FS. Öğrenci seçme sınavına hazırlanan gençlerle sınav kaygısının psikodrama yoluyla çalışılması, Psikodrama Tezi Abdülkadir Özbek Psikodrama Enstitüsü. 2007.

40. Gökengin B. Bir grup lise öğrencisi ile psikodrama çalışması, Psikodrama Tezi. Abdülkadir Özbek Psikodrama Enstitüsü. 2006.

41. Karataş Z. Bilişsel davranışçı teknikler ile psikodrama teknikleri kullanılarak yapılan grupla psikolojik danışma uygulamalarının ergenlerdeki saldırganlığa azaltmadaki etkilerinin karşılaştırılmalı olarak incelenmesi, Doktora Tezi. 2008.

42. Erdoğan ŞA. Travma yaşantısı olan üniversite öğrencilerinin baş etme becerilerini geliştirmede psikodramanın etkisi, Yüksek Lisans Tezi, Marmara Üniversitesi. 2010.

43. Karataş Z. Psikodrama teknikleri kullanılarak yapılan grupla psikolojik danışma uygulamalarının ergenlerin çatışma çözme becerilerine etkilerinin incelenmesi, Kuram ve Uygulamada Eğitim Bilimleri Dergisi. 2011;11(2):60114.
44. Albayrak G. Psiko-eğitim programı ile psikodramanın üniversite öğrencilerinin psikolojik iyi oluşlarına etkisinin karşılaştırılması, Doktora Tezi, Mersin Üniversitesi. 2013.

45. Akinsola FE, Udoka AP. Parental Influence on Social Anxiety in Children and Adolescents: Its Assessment and Management Using Psychodrama. Psychology. 2013;4(3):246-53. [CrossRef]

46. Dehnavi S, Hadadi Z, Jelveh M, Safaryazdi Z, Panahi P. The Effectiveness of Psychodrama in the Reduction of Social Anxiety Disorderamong Male Adolescents. The Neuroscience Journal of Shefaye Khatam. 2014;2(3):1.

47. Şimşek Ç, Yıldırım EA. Psikodramanin ergenlerde empati ve sosyal anksiyete duzeyine etkisi. Poster bildiri. XLIII. Uluslararası Katılımlı Grup Psikoterapileri Kongresi, 23-26 Mayis 2018 Asklepion-Bergama/İzmir

48. Şimşek Ç, Yıldırım EA, Kayır A. ihmal ve istismara uğramış çocuklarla psikodrama. Sözlü Bildiri. V. Uluslararası IX. Ulusal Psikiyatri Hemşireliği Kongresi 20-23 Kasım - November 2018, Antalya.

49. Doğan T. The effects of the psychodrama in instilling empathy and self-awareness: A pilot study. Psy Ch Journal. 2018;7:227-38. [CrossRef]

50. Pratama SY, Wibowo EM, Awalya M. Group Counseling with Psychodrama and Sociodrama Techniques to Improve Emotional Intelligence. Journal Bimbingan Konseling. 2019;8(1):79-85. 